\title{
Forest spatial heterogeneity and palm richness, abundance and community composition in Terra Firme forest, Central Amazon
}

\author{
RENATO CINTRA ${ }^{1,3}$, ARIMATÉA DE CARVALHO XIMENES ${ }^{2}$, FÁBIO R. GONDIM² and \\ MARCELA S. KROPF ${ }^{2}$
}

(received: September 18, 2003; accepted: November 5, 2004)

\begin{abstract}
Forest spatial heterogeneity and palm richness, abundance and community composition in terra firme forest, Central Amazon). The mechanisms that maintain tree diversity in tropical rain forests are still in debate. Variations in forest structural components produce forest microenvironmental heterogeneity, which in turn may affect plant performance and have been scarcely analyzed in the Amazon. Palms are widespread in the Neotropical rainforests and have relatively well known taxonomy, apart from being ecologically and economically important. The understanding of how palms respond to variation in the forest structural components may help to explain their abundance and richness in a given area. In this study, we describe a palm community and analyze how it is affected by forest microenvironmental heterogeneity. In a pristine "Terra Firme" forest at Reserva Ducke, Manaus, we recorded all adult palm trees in twenty $100 \times 10 \mathrm{~m}$ plots. In the same plots we recorded the variation in canopy openness, the leaflitter thickness and counted all non-palm forest trees. A total of 713 individuals in 29 palm species were found. The three most abundant species were Astrocaryum sciophilum (Miq.) Pulle, A. gynacanthum Mart. and Attalea attaleoides (Barb. Rodr.) Wess. Boer. The most locally abundant species were also very frequent or occurred in a larger number of plots. There were no significant effects of litter depth, forest canopy openness and forest tree abundance on palm richness. However, in areas where leaf litter was thicker a significant lower number of palm trees occurred. In microsites where proportionally more incident light was reaching the forest understory, due to higher canopy opening, significantly more palm trees were present.
\end{abstract}

Key words - Amazonia, canopy openness, leaf litter, palm community, Reserva Ducke

RESUMO - (A heterogeneidade espacial da floresta e a riqueza, abundância e composição da comunidade de palmeiras em floresta de terra firme na Amazônia Central). Os mecanismos que mantêm a diversidade de plantas em florestas tropicais estão ainda em debate. Variações nos componentes estruturais da floresta produzem heterogeneidade microambiental na floresta, que por sua vez devem afetar as plantas, e raramente têm sido analisados na Amazônia. As palmeiras são amplamente distribuídas em florestas neotropicais e tem a sua taxonomia bem conhecida, além de sua importância ecológica e econômica. O entendimento de como as palmeiras respondem às variações nos componentes estruturais da floresta pode ajudar a explicar a abundância e a riqueza delas em uma dada área. Neste estudo descrevemos uma comunidade de palmeiras e analisamos como ela é afetada pela microheterogeneidade ambiental da floresta. Em uma floresta de terra firme na Reserva Ducke, Manaus, registramos todas as palmeiras adultas em 20 parcelas de $100 \times 10 \mathrm{~m}$. Nas parcelas também registramos a variação na abertura do dossel, a profundidade de folhiço e o número de árvores da floresta. Setecentos e treze indivíduos de 29 espécies de palmeiras foram registrados. As três espécies mais abundantes foram Astrocaryum sciophilum (Miq.) Pulle, A. gynacanthum Mart. and Attalea attaleoides (Barb. Rodr.) Wess. Boer. As palmeiras mais abundantes localmente também foram muito frequentes e ocorreram na maioria das parcelas. Não houve efeito significativo da profundidade de folhiço, abertura do dossel da floresta e abundância de árvores, na riqueza de espécies de palmeiras. Em microsítios com maior profundidade de folhiço ocorreu significativamente menor abundância de palmeiras. Quanto maior a abertura do dossel da floresta, um número significativamente maior de palmeiras estava presente.

Palavras-chave - abertura do dossel, Amazonia, comunidade de palmeiras, folhiço, Reserva Ducke

\section{Introduction}

The mechanisms that maintain tree diversity in tropical rain forests are still in debate by tropical biologists. Many interesting studies have been published on how

1. Instituto Nacional de Pesquisas da Amazônia, Departamento de Ecologia, Caixa Postal 478, 69011-970 Manaus, AM, Brasil.

2. Universidade Santa Ursula, Rua Fernando Ferrari 75, 22231-040 Rio de Janeiro, RJ, Brasil.

3. Corresponding author: cintra@inpa.gov.br forest environmental heterogeneity affects plant richness and distribution in the tropical rain forest. Some studies defend the idea that the high tree richness of tropical rain forests could be a result of stochastic events such as the physical action of tree-fall gaps, which creates space and more illuminated environment for plants to colonize (Brandani et al. 1988, Swaine \& Whitmore 1988, Condit et al. 1996). Because of the similar ability for competition among species to colonize frequent created gaps there will always be a high number of tree species in a given site (Hubbell \& Foster 1986). 
Some authors tried to explain plant richness in tropical rain forests based on meso-scale environmental heterogeneity, such as niche differentiation (Ricklefs 1977, Connell 1978, Ashton 1989, Clark et al. 1998,1999) and negative density dependence (Janzen 1970, Clark \& Clark 1984, Terborgh et al. 1996). However, in any environment most of plant population and community are submitted to a relatively high degree of small-scale environmental heterogeneity (Fowler 1988, Svenning 1999).

Apart from being ecologically and economically important, palms are one of the most abundant, and widespread plant families in Neotropical rainforests and their taxonomy is relatively well known (Gentry 1991, Henderson et al. 1995). Palm fruits, seeds and seedlings are consumed both by invertebrates and vertebrates and in some sites, in periods of scarcity of fruits in the forest, palms are among the few available food resources to support vertebrate biomass (Terborgh 1986). In the Amazon region palms have been traditionally used by humans for food and many other purposes including house construction.

Some studies on palm distribution and abundance have been conducted in the Amazon forest to describe plant community distribution in a type of habitat and to compare it among different habitats (Kahn \& Castro 1985, Kahn \& Mejia 1990). Although studies on distribution and abundance of palms are available, they are still scarce. However, in the Amazon forest the effects of plant community succession (Losos 1995), forest fragmentation and edge effects (Scariot 1999), soil conditions (Peres 1994), leaf litter thickness (Cintra 1997a), tree-fall gap size and distance to the nearest gap (Uhl et al. 1988, Cintra \& Horna 1997, Svenning 2000), seedling density and distance to the nearest neighbor and adult (Cintra 1997b), vegetation cover and light (Cintra \& Terborgh 2000) have been demonstrated to affect palm seedling growth and survival and adult community composition. In the Brazilian Atlantic forest palms density dependence seems to be important only during the seedling stage (Matos et al. 1999).

Apart from studies analyzing the effects of forest fragmentation, soil conditions and plant succession (Scariot et al. 1989, Peres 1994, Losos 1995) there is scarce information on how variation in the degree of forest environmental heterogeneity affects the palm community.

The forest environmental heterogeneity produced by variation in the amount of incident light (i.e. degree of variation in forest non-tree fall canopy openness), the type of substrate (i.e. spatial variation in the amount of leaf-litter) and density of other forest tree species may be important in determining where and why a given individual palm tree has successfully established in the forest (Kiltie 1981, Denslow 1987, De Steven 1988, Losos 1995, Cintra 1998, Cintra \& Terborgh 2000). The use of these variables to investigate their effects on adults, instead of seedlings, may sound strange because most of the adult palms have established themselves when the forest floor dynamics, in terms of the amount of accumulated leaf litter, could have been different. Even today, leaf litter accumulation is known to vary seasonally and annually (Luizão \& Schubart 1987). However, we do not believe that forest conditions would change so fast, in its ecological and evolutionary dynamics, to drastically affect the overall leaflitter accumulation.

Few studies have considered the combined effects of these factors on palm richness and community composition. These factors and many others are components of the forest heterogeneity and the degree of small-scale variation in each may contribute to affect the richness and composition of plant community (Ricklefs 1977). For instance, palm abundance can affect the growth and survival of seedlings of other tree species (Denslow et al. 1991), but also can be affected by shading of other tree species. Shading may create good conditions for palm seeds to germinate but bad conditions for seedlings to grow. A recent and excellent review on the role of microenvironmental heterogeneity on palms concluded that, the ecology of neotropical palms is significantly influenced by small-scale environmental heterogeneity, which sometimes leads to more than 30 palm species coexisting in given area (Svenning 1999, 2001). Among the myriad of forest heterogeneities, and since the Cretaceous, the disturbance and edaphic conditions have been advocated to affect palm distribution at small spatial scale as well (Wing et al. 1993).

Palm growth and mortality in the "terra firme" forest is very dynamic. There might be a significant range of variation in many forest structural components that could produce forest microenvironmental heterogeneity affecting the palm performance, and their effects on forest plants have been scarcely analyzed in the Amazon (but see Svenning 1999, 2001). The understanding of how palms respond to variation in the forest structural components may help to explain their local abundance and richness. It could also subsidize forest management and conservation actions to use palms in a sustainable way.

In this study we describe a palm community in terms of its components (species richness, abundance and community composition), in a site where access 
was just recently created in a "terra firme" forest in Central Amazon. This was a good opportunity to work in a pristine community. As far as we know, in the Brazilian Amazon forest only one study with palms under similar conditions has been done (Peres 1994).

Apart from describing the palm community composition, we wanted to verify whether the most abundant species in a given microsite was also among the most frequent in the area. We also investigated how variations in non-palm forest tree abundance, in the degree of forest canopy openness and in leaf litter depth, affected the palm abundance, richness and community composition.

\section{Material and methods}

The study was conducted during the rainy season (January - February, 2001), at INPA's Reserva Ducke, located $25 \mathrm{~km}$ from Manaus $\left(03^{\circ} 08^{\prime} \mathrm{S}\right.$ and $\left.60^{\circ} 04^{\prime} \mathrm{W}\right)$. The Reserve has an area of 10,000 ha. The annual rainfall in the area is about $2,500 \mathrm{~mm}$. Vegetation is a Terra Firme primary tropical rain forest which is never seasonally inundated by river level fluctuations. The soil is a oxysol, and the area has many small streams resulting in a topography of lowlands intercalated with plateaus reaching an altitude up to $140 \mathrm{~m}$ (Ribeiro et al. 1999).

We recorded all fruiting adult palm trees showing fruits, including those with evidence that have had fruited before (presenting racemes with old and dried fruits still attached), in twenty $100 \times 10 \mathrm{~m}$ plots separated $200 \mathrm{~m}$ from one another along the four sides of a 100 ha block located in the continuous forest on the eastern side of the Reserve. Plots were always located on the right side of the trails and at least $3 \mathrm{~m}$ from the trail.

Our study area is part $(1 / 64)$ of a grid of trails $(8 \times 8 \mathrm{~km})$ located at $1 \mathrm{~km}$ intervals covering 6,400 ha of the whole Reserve. In the $100 \times 10 \mathrm{~m}$ plots, the number of leaf litter layers was counted at the center and corners of ten $1 \mathrm{~m}^{2}$ subplots in a transect of $10 \times 1 \mathrm{~m}$ starting at the beginning of each of the twenty $100 \times 10 \mathrm{~m}$ plots. The variation in the forest canopy openness was recorded in the same ten subplots using a Spherical Crown Densiometer (Concave model C - Robert E. Lemonn, Forest Densiometers, 5733 SE Cornell Dr. Bartlesville, OK, USA), and four reading estimates were taken, each oriented towards the cardinal points, east, west, south and north. All forest trees above $5 \mathrm{~cm} \mathrm{DBH}$ (diameter at breast height) were also counted within each $100 \times 10 \mathrm{~m}$ plots. Finally, we counted all arborescent and non-arborescent adult palm trees, within the same twenty $100 \times 10 \mathrm{~m}$ plots. Only individual adult palms were considered, that is, those palms with evidence of reproductive activities (showing recent and/or old fruits). Palms were identified in the field using a book, the field guide of identification for vascular plants of Reserva Ducke (Ribeiro et al. 1999) and the help of one of the book's author, (Assunção, P.A.C.L). Statistical analysis - To verify the effects of the independent variables (i.e. leaf litter depth, forest canopy openness and non-palm forest tree abundance) on the dependent variables (i.e. palm richness and palm abundance) we constructed a multiple regression analysis model for each dependent variable using Systat (Wilkinson 1998). To analyze palm community composition, we used the number of adult palm tree to construct a quantitative data matrix: the rows (objects) are sites - the experimental plots - and the columns (attributes) are the abundance or number of each palm species recorded. Similarities in palm community composition, in the twenty 100 $\times 10 \mathrm{~m}$ plots, were verified by using a multidimentional scaling ordination analysis (MDS). This ordination analysis technique has a test for the significance of the independent variables and shows the relationship between objects in two dimensions. A dissimilarity matrix was constructed using the Bray-Curtis index on the raw data matrix. This index has been highly recommended for use in ecological studies (Minchin 1987, MacNally 1994). The MDS analysis was used to generate a single ordination of palm species within sites (plots) based on the Bray-Curtis distance matrix. The computer program PATN (Belbin 1982) was used to run the ordination multivariate analysis. The Bray-Curtis index is calculated according to the following formula:

$$
\mathrm{D}=\left.\Sigma\right|^{\mathrm{D} i \mathrm{k}}-\mathrm{D}^{\mathrm{j} k} \mid / \Sigma\left({ }^{\mathrm{D}} \mathrm{ik}+{ }^{\mathrm{D}} \mathrm{jk}\right)
$$

Where, ${ }^{\mathrm{D}} \mathrm{ik}=$ the data value for the ith row and $\mathrm{k}^{\text {th }}$ column of the data matrix; ${ }^{\mathrm{D} j \mathrm{k}}=$ the data value for the $\mathrm{j}^{\text {th }}$ row and $\mathrm{k}^{\text {th }}$ column of the data matrix.

Because this index may put more weight on more abundant species, the palm species abundance values in the raw data matrix were standardized by dividing each one by the total of their sum. The resulting MDS1 and MDS2 scores from the ordination analysis were used as dependent variables in a multivariate multiple regression analysis in which model the independent variables were the following: (1) leaf litter depth, (2) forest canopy openness, and (3) abundance of forest trees. Finally, a multivariate and robust test (Pillai-Trace) was used to verify whether changes in palm community composition were significantly affected by the above three independent variables. This analysis was done using the program Systat (Wilkinson 1998).

\section{Results}

A total of 713 individuals of 29 breeding palm species were found in the 20 plots. The three most abundant species were Astrocaryum sciophilum (Miq.) Pulle, Astrocaryum gynacanthum Mart. and Attalea attaleoides (Barb. Rodr.) Wess. Boer. (table 1). Astrocaryum sciophilum (Miq.) Pulle was as much as twice more abundant than the second and third more abundant species. 
Bactris elegans Barb. Rodr and Oenocarpus bataua Mart. were the $4^{\text {th }}$ and $5^{\text {th }}$ most abundant in the samples (table 1) but these two species had the highest abundance of individuals (25) in a given plot. Oenocarpus minor Mart. and Oenocarpus bataua Mart., were present in low numbers whenever they occurred, however they were present in about $40 \%$ of the sampled plots (table 2). Six palm species (about 20\%) were very scarce and occurred only once in the plots surveyed.
In general, the most "locally" abundant species also had a higher "regional" frequency or occurred in a larger number of plots (table 1, figure 1). There was a significant relationship between palm density and the frequency of occurrence in the plots $\left(r^{2}=0.51 ; n=29\right.$; $\mathrm{DF}=1 ; \mathrm{F}=29.173 ; \mathrm{P}<0.0001)$.

There were no significant effects of litter depth, forest canopy openness and forest tree abundance on palm richness (table 3, figure 2). However, there were significant effects of leaf litter depth and forest

Table 1. Number of individuals, densities, and frequency of reproductive individuals (adult palms) recorded in Terra Firme Forest at Reserva Ducke in the Central Amazon.

\begin{tabular}{|c|c|c|c|c|}
\hline $\begin{array}{r}\text { Total } \\
\text { indi }\end{array}$ & $\begin{array}{l}\text { tal number of } \\
\text { individuals } \\
\text { (a) }\end{array}$ & $\begin{array}{c}\text { Average abundance } \\
\text { (adults / 200.1 ha) } \\
\text { (a / 20) }\end{array}$ & $\begin{array}{c}\text { Maximum } \\
\text { abundance per plot }\end{array}$ & Frequency $^{*}$ \\
\hline Astrocaryum sciophilum (Miq.) Pulle & 193 & 9.65 & 19 & 19 \\
\hline Astrocaryum gynacanthum Mart. & 90 & 4.50 & 13 & 18 \\
\hline Attalea attaleoides Wess. Boer & 87 & 4.35 & 18 & 17 \\
\hline Bactris elegans Barb. Rodr. & 76 & 3.80 & 25 & 12 \\
\hline Oenocarpus bataua Mart. & 44 & 2.05 & 25 & 4 \\
\hline Bactris acanthocarpa Mart. var. humilis Bar. Rodr. & 30 & 1.40 & 8 & 10 \\
\hline Geonoma deversa (Poit.) Kunth & 29 & 1.30 & 5 & 11 \\
\hline Euterpe precatoria Mart. & 20 & 1.0 & 9 & 8 \\
\hline Oenocarpus bacaba Mart. & 18 & 0.95 & 2 & 11 \\
\hline Oenocarpus minor Mart. & 18 & 0.90 & 3 & 10 \\
\hline Bactris maraja Mart. var. maraja & 17 & 0.85 & 16 & 2 \\
\hline Attalea microcarpa Mart. & 12 & 0.60 & 6 & 2 \\
\hline Bactris gastoniana Barb. Rodr. & 11 & 0.55 & 4 & 4 \\
\hline Geonoma aspidifolia Spruce & 10 & 0.50 & 5 & 4 \\
\hline $\begin{array}{l}\text { Bactris tomentosa Mart. var. sphaerocarpa } \\
\text { (Mart.) Henderson }\end{array}$ & 11 & 0.50 & 4 & 3 \\
\hline Syagrus inajai (Spruce) Becc. & 9 & 0.45 & 2 & 6 \\
\hline Socratea exorrhiza (Mart.) H. Wendl. & 9 & 0.45 & 3 & 5 \\
\hline Iriartella setigera (Mart.) H. Wendl. & 6 & 0.30 & 1 & 5 \\
\hline Geonoma maxima (Poit.) var. maxima & 6 & 0.30 & 3 & 3 \\
\hline $\begin{array}{l}\text { Astrocaryum murumuru Mart. var. ferrugineum } \\
\text { (Kahn \& Millan) Henderson }\end{array}$ & 5 & 0.25 & 2 & 4 \\
\hline Bactris killipii Burret & 2 & 0.10 & 1 & 2 \\
\hline Desmoncus polyacanthus Mart. & 2 & 0.10 & 1 & 2 \\
\hline $\begin{array}{l}\text { Bactris acanthocarpa Mart. var. trailiana } \\
\text { (Barb. Rodr.) Henderson }\end{array}$ & 2 & 0.10 & 1 & 2 \\
\hline Bactris hirta Mart. & 1 & 0.05 & 1 & 1 \\
\hline Bactris simplicifrons Mart. & 1 & 0.05 & 1 & 1 \\
\hline Geonoma stricta (Poit.) Kunth var. stricta & 1 & 0.05 & 1 & 1 \\
\hline $\begin{array}{l}\text { Geonoma maxima (Poit.) Kunth var. spixiana } \\
\text { (Mart.) Henderson }\end{array}$ & 1 & 0.05 & 1 & 1 \\
\hline $\begin{array}{l}\text { Geonoma maxima (Poit.) Kunth var. chelidonura (Spruce) } \\
\text { Henderson }\end{array}$ & e) 1 & 0.05 & 1 & 1 \\
\hline Mauritia flexuosa L.f. & 1 & 0.05 & 1 & 1 \\
\hline
\end{tabular}

* Number of plots in which the palm species occurred. 
Table 2. Abundance of adult palms in terra firm forest at Reserva Ducke, Central Amazon.

\begin{tabular}{llllllllllllllllllllllll}
\hline Plot number & 1 & 2 & 3 & 4 & 5 & 6 & 7 & 8 & 9 & 10 & 11 & 12 & 13 & 14 & 15 & 16 & 17 & 18 & 19 & 20 & Total
\end{tabular}

Palm species*

\begin{tabular}{|c|c|c|c|c|c|c|c|c|c|c|c|c|c|c|c|c|c|c|c|c|}
\hline Astrocaryum sciophilum (Miq.) Pulle ${ }^{1}$ & 16 & 18 & 10 & 8 & 11 & & 11 & & 11 & & 19 & 10 & & 16 & 13 & & 10 & 31 & 4 & 193 \\
\hline Astrocaryum gynacanthum Mart. ${ }^{4}$ & & 1 & 4 & 3 & 4 & 3 & 4 & 1 & 2 & 2 & 9 & 13 & 9 & 6 & 2 & & 9 & 8 & 2 & 90 \\
\hline Attalea attaleoides Wess.Boer ${ }^{1}$ & 2 & & 11 & 2 & 3 & 6 & 6 & & 7 & 5 & 3 & 5 & 41 & 18 & 4 & & 1 & 3 & 2 & 87 \\
\hline Bactris elegans Barb. Rodr. ${ }^{3}$ & & 1 & & 3 & & 32 & 25 & 1 & 9 & 7 & 2 & 7 & 11 & & 3 & & 4 & & & 76 \\
\hline Oenocarpus bataua Mart. $^{5}$ & 1 & 2 & & & & & & 13 & & & & & & & & 5 & & & 3 & 44 \\
\hline Geonoma deversa (Poit.) Kunth ${ }^{3}$ & & & 1 & 1 & 3 & 2 & 4 & 4 & 1 & 4 & 1 & 3 & 1 & & & & 5 & & & 30 \\
\hline $\begin{array}{l}\text { Bactris acanthocarpa Mart. var. humilis } \\
\text { Bar. Rodr. }{ }^{1}\end{array}$ & 1 & & & & & 1 & & & & 3 & & 3 & 2 & 8 & 2 & & 2 & 4 & 3 & 29 \\
\hline Euterpe precatoria Mart. $^{5}$ & & & 2 & 2 & & 1 & 1 & 2 & & & & & 2 & & & 9 & 1 & & & 20 \\
\hline Oenocarpus minor Mart. $^{5}$ & & 3 & 2 & & & & 1 & & 2 & 1 & 2 & & & 2 & & & 3 & & 1 & 18 \\
\hline Bactris maraja Mart. var. maraja ${ }^{3}$ & & & & & & & & & & & & & & & 1 & 6 & & & & 17 \\
\hline Oenocarpus bacaba Mart. $^{5}$ & & 1 & & & 2 & 1 & & & 1 & 1 & & 1 & 2 & 1 & 1 & & & & 1 & 12 \\
\hline Attalea microcarpa Mart. $^{1}$ & & 6 & & & & & & & & & & & & & & & & & 6 & 12 \\
\hline Bactris gastoniana Barb. Rodr. ${ }^{2}$ & & & & & & 4 & 2 & & 2 & & 1 & & & & 2 & & & & & 11 \\
\hline $\begin{array}{l}\text { Bactris tomentosa Mart. var. sphaerocarpa } \\
\text { (Mart.) Henderson }{ }^{2}\end{array}$ & & 1 & 1 & 4 & 4 & & & & 1 & & & & & & & & & & & 11 \\
\hline Geonoma aspidifolia Spruce $^{2}$ & & 1 & 2 & 5 & & & & & & & & & & & & & & 2 & & 10 \\
\hline Syagrus inajai (Spruce) Becc. ${ }^{5}$ & & & & & & 2 & & & & & & 1 & 2 & & 2 & & & 1 & 1 & 09 \\
\hline Socratea exorrhiza (Mart.) H. Wendl. ${ }^{5}$ & & & & & & & 2 & 1 & & & & & & & & 3 & 2 & & 1 & 09 \\
\hline Iriartella setigera (Mart.) H. Wendl. ${ }^{4}$ & 1 & 1 & & & 1 & & & & 1 & & & 1 & 1 & & & & & & & 06 \\
\hline Geonoma maxima (Poit.) var. maxima ${ }^{3}$ & & & 2 & & & 3 & & & & & 1 & & & & & & & & & 06 \\
\hline $\begin{array}{l}\text { Astrocaryum murumuru Mart. var. } \\
\text { ferrugineum (Kahn \& Millan) Henderson }\end{array}$ & & & 1 & 2 & & & & & & & & & & 1 & & & & & 1 & 05 \\
\hline Bactris killipii Burret ${ }^{2}$ & & & & & & & & & & & & 1 & & & 1 & & & & & 02 \\
\hline Desmoncus polyacanthus Mart. $^{6}$ & & & 1 & & & & & & & & & & & & & & & & 1 & 02 \\
\hline $\begin{array}{l}\text { Bactris acanthocarpa Mart. } \\
\text { var. trailiana (Barb. Rodr.) Henderson }{ }^{2}\end{array}$ & & & & & & & & & & 1 & 1 & & & & & & & & & 02 \\
\hline${\text { Bactris hirta } \text { Mart. }^{2}}^{2}$ & 1 & & & & & & & & & & & & & & & & & & & 01 \\
\hline Bactris simplicifrons Mart. $^{2}$ & & & & & & & & & & & & & & & & & & 1 & & 01 \\
\hline Geonoma stricta (Poit.) Kunth var. stricta ${ }^{2}$ & & & & & & & & & & 1 & & & & & & & & & & 01 \\
\hline $\begin{array}{l}\text { Geonoma maxima (Poit.) Kunth } \\
\text { var. spixiana (Mart.) Henderson }\end{array}$ & 1 & & & & & & & & & & & & & & & & & & 01 & \\
\hline $\begin{array}{l}\text { Geonoma maxima (Poit.) Kunth } \\
\text { var. chelidonura (Spruce) Henderson }{ }^{3}\end{array}$ & & & & & & & 1 & & & & & & & & & & & & & 01 \\
\hline Mauritia flexuosa L.f. $^{5}$ & & & & & & & & & & & & & & & & 1 & & & & 01 \\
\hline Total & & & & & & & & & & & & & & & & & & & & 713 \\
\hline
\end{tabular}

* Numbers after scientific names corresponds to palm life forms $(1=$ subterraneous stems, leaves can reach up to $7 \mathrm{~m}$ height $2=$ understory treelets up to $3 \mathrm{~m}$ height $1 \mathrm{~cm}$ DAP $3=$ understory trees 3-7 m height and 2-5 cm DAP $4=$ trees up to $12 \mathrm{~m}$ height $4-10 \mathrm{~cm}$ DAP $5=$ trees up to $25 \mathrm{~m}$ height 15-60 cm DAP 6 = Liana; information on palms size were taken from Ribeiro et al. 1999).

canopy openness on palm abundance (table 4, figure 3 ). The abundance of adult palms was inversely related to leaf litter depth. However, palm abundance was directly related to canopy openness.

Finally, the results of multivariate multiple regression analyses indicated that there were no significant effects of leaf litter depth (Pillai Trace Test $=0.147 ; \mathrm{P}=0.304$ ), canopy openness (Pillai Trace $=0.256 ; \mathrm{P}=0.109$ ) or forest tree abundance (Pillai Trace $=0.065 ; \mathrm{P}=0.606$ ) on palm community composition.

\section{Discussion}

The pattern of species richness and abundance found in this study confirmed what was found in general for tree communities in the Amazon forest. Some species 


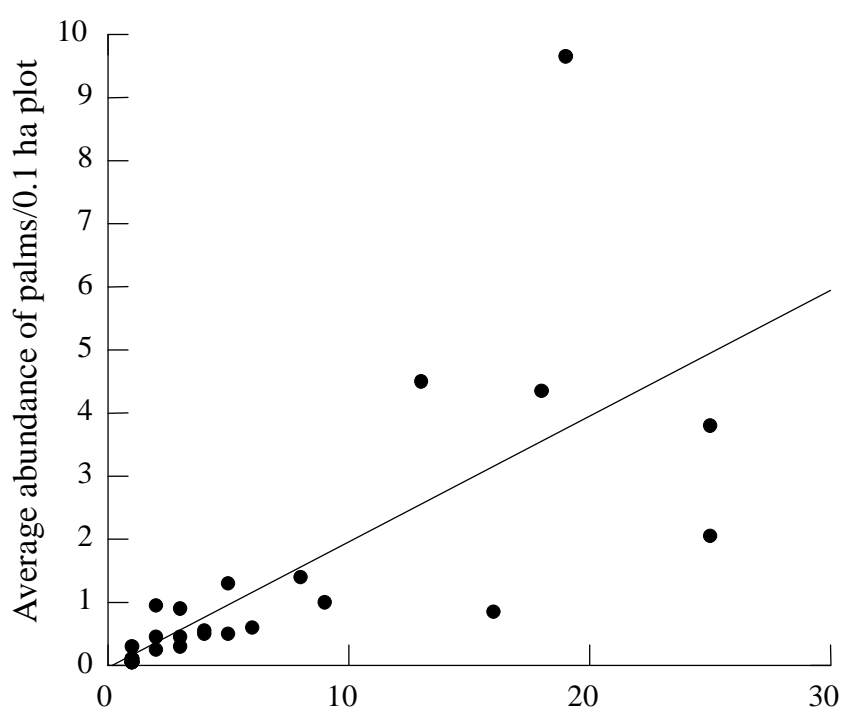

Number of plots in which the palm species ocurred

Figure 1. Relationship between palm density and frequency of occurrence in twenty 0,1 ha plots (the equation is $y=-0.633 x+0.315$, see also result section) in a Terra firme forest, Reserva Ducke, Manaus.

were "rare" or occurred in low abundance "locally" but they were relatively frequent "regionally" or occurred in many of the sampled plots, and few species are very abundant.

In the Peruvian Amazon, Pitman et al. (1999) recorded trees species in 21 plots totaling 36 hectares within an area of $400 \mathrm{~km}^{2}$. They found 825 tree species, with about $88 \%$ of them at densities of $<1$ individuals/ha. They concluded that most trees species in the region were habitat generalist and widely distributed over Amazon Region.
Kahn et al. (1988) comparing palm community composition in eastern, central and western Amazon forest found palm species richness to be high in western site and in "terra firme" forests which was dominated by understory palm species under $10 \mathrm{~m}$ in height. In their own words, "the largest and one of the most diversified palm communities of the world is mainly represented by small understory species". They found that adult arborescent palm are very uncommon in "terra firme" forest but the opposite was true for seasonal swamp forests (Kahn et al. 1988). The same author studying palms in wetland forest in the lower Ucayali valley in Peru found 11 species in a 4 ha plot, with five of them representing $98.9 \%$ of the community (Kahn \& Mejia 1990).

We found that the five most abundant species represented $68.7 \%$ of the community sampled (tables $1,2)$. These differences in palm abundance between our study and Kahn's study could be because our area is a non-flooded "terra firme" forest and had more than twice the number of palm species. Even some species adapted to survive well in occasionally flooded forest or along forest streams such as Socratea exorhiza (Mart.) H. Wendl., Mauritia flexuosa L.f. occurred in very small number in our plots.

Scariot et al. (1989) studying palms in a seasonal swamp in eastern Amazon found eight palm species with 3,975 individuals in an area of one hectare. They found that just one species Orbignya phalerata Mart. (= Attalea speciosa Mart. = Attalea glassmanii Zoua) represented $60 \%$ of this individuals and it occurred in great density in less humid areas. The authors suggested that the dominance of this species in the area could be due to high light intensity as a limiting factor and not

Table 3. Results of the multiple regression analysis of the effects of litter depth, forest canopy openness and forest tree abundance on Palm richness in Terra Firme forest, Reserva Ducke, Manaus $\left(\mathrm{R}^{2}=0.112\right)$.

\begin{tabular}{lcccccc}
\hline Effect & Coef & Std. Error & Std. Coef. & Tolerance & t & P \\
\hline Constant & 9.421 & 3.246 & 0.000 & - & 2.903 & 0.010 \\
Litter depth & -0.248 & 0.227 & -0.291 & 0.782 & -1.093 & 0.290 \\
Canopy openness & -0.057 & 0.297 & -0.051 & 0.766 & -0.191 & 0.851 \\
Tree abundance & 0.014 & 0.053 & 0.063 & 0.953 & 0.262 & 0.797 \\
\multicolumn{7}{c}{} \\
Source & Analysis of Variance & F-ratio & P \\
Regression & Sum-of-Squares & DF & Mean-Square & & 0.674 & 0.580 \\
Residual & 6.572 & 3 & 2.191 & & & \\
\hline
\end{tabular}



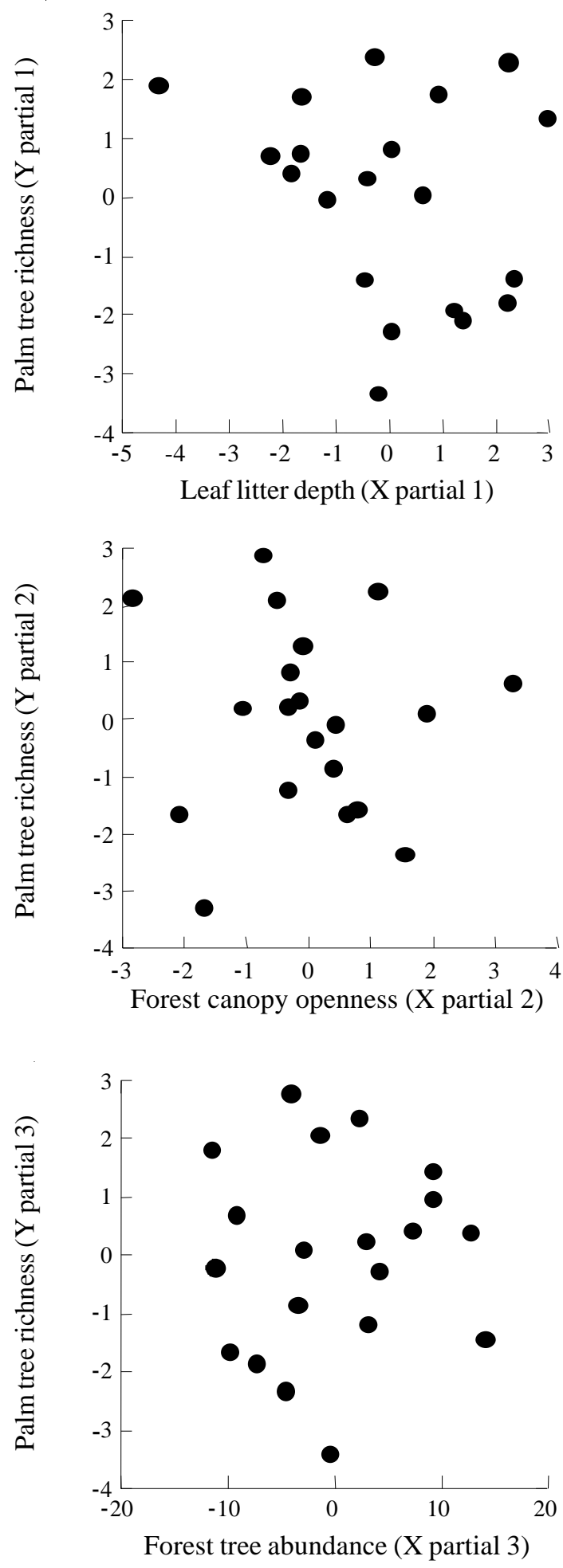

Figure 2. Partials of the multiple regression analysis on the effects of leaf litter depth (A), forest canopy openness (B), and forest tree abundance $(\mathrm{C})$ on the dependent variable Palm richness. The partials resulted from the analysis presented in the table 2 . Some numbers in the axis have negative values because the partial regression represents the deviation of the expected results if all other independent variables are hold constant in their observed means.
A water, because the seedlings were less abundant near the water.

The number of palm species recorded in our study is relatively high considering the area sampled $\left(20,000 \mathrm{~m}^{2}\right)$. We registered 29 palm species corresponding to $52 \%$ of the species occurring in the 10,000 ha area of the Reserva Ducke (Ribeiro et al. 1999). Our results were similar to those in a study conducted earlier at another INPA reserve, located $45 \mathrm{~km}$ from Reserva Ducke, in which 32 palm species were found in 1.2 ha (Kahn \& Castro 1985).

We found Astrocaryum sciophilum (Miq.) Pulle, A. gynacanthum Mart. and Attalea attaleoides (Barb. Rodr.) Wess. Boer, to be the three most abundant palms in our area (table 1). Astrocaryum sciophilum (Miq.) Pulle was by far the most abundant and it occurred as much as twice as the second and third most abundant species. Two palm species, Oenocarpus minor Mart. and $O$. bataua Mart., were in low number wherever they occurred, however they were present in about $40 \%$ of the sampled plots (table 2). This suggests that Oenocarpus palms are relatively rare in a given microsite but they can occur in extensive areas in the forest and therefore tolerant to some degree of variation in the meso-scale forest heterogeneity conditions. It may also indicate that the microsites for these two species to establish are patchy in our area. This environmental heterogeneity may favor the local coexistence of such a high number of palm species (Svenning 2001).

Some of the palm species recorded in our survey Astrocaryum sciophilum (Miq.) Pulle, A.gynacanthum Mart., Attalea attaleoides (Barb. Rodr.) Wess. Boer, Oenocarpus bataua Mart., Euterpe precatoria Mart., Socratea exorhiza (Mart.) H. Wendl., Mauritia flexuosa L.f., and some others, are relatively widely distributed in the Amazon region in areas distant and can be found more than $1,000 \mathrm{~km}$ from our study site (Henderson 1995). Their relatively large range of occurrence suggests that these species may be very tolerant to a large variation in a gradient of environmental conditions of light incidence, soil, nutrient, humidity, and topographic levels. More studies surveying plots scattered throughout the region are needed to verify how the isolated and combined effects of these factors at large spatial scale affect palm distribution and variation in their community composition. Studies considering large spatial scale samples would also help to verify how strong the relationship is between local and regional plant diversity in the Amazon.

In tropical rain forest both leaf litter cover and leaf litter depth contribute to microenvironmental 
Table 4. Results of the multiple regression analysis of the effects of litter depth, forest canopy openness, and forest tree abundance on Palm abundance in Terra Firme forest, Reserva Ducke, Manaus. $\left(R^{2}=0.427\right)$

\begin{tabular}{lcccccc}
\hline Effect & Coef & Std. Error & Std. Coef. & Tolerance & t & P \\
\hline Constant & 52.150 & 16.141 & 0.000 & - & 3.231 & 0.005 \\
Leaf litter depth & -2.491 & 1.127 & -0.473 & 0.782 & -2.211 & 0.042 \\
Canopy openness & 4.174 & 1.476 & 0.611 & 0.766 & 2.827 & 0.012 \\
Tree abundance & -0.353 & 0.261 & -0.262 & 0.953 & -1.350 & 0.196 \\
\multicolumn{7}{c}{ Analysis of Variance } \\
Source & Sum-of-Squares & DF & Mean-Square & & F-ratio & P \\
Regression & 957.536 & 3 & 319.179 & & 3.973 & 0.027 \\
Residual & 1285.414 & 16 & 80.338 & & & \\
\hline
\end{tabular}

heterogeneity and are spatially unpredictable even at scales of few meters (Molovsky \& Augspurger 1992, Cintra 1997a). In the Reserva Ducke, the microsite variation in leaf litter depth did not affect palm species richness, however it was inversely related to palm abundance, suggesting that palms are in higher numbers in areas of shallow leaf litter. The spatial variation in the amount of leaf litter and other forms of litter affect palm survival during the early stages of plant establishment probably by protecting from predation for both, seeds from large-seeded palms in microsites with thick litter (Cintra 1997a) and small-seeded palms in areas of thin litter layer (Svenning 2001).

The variation in the degree of canopy openness was directly related to palm abundance (table 4). More palms were found in microsites bearing larger canopy openness than in those microsites with small canopy openness. This is a result we would expect because where there is more canopy discontinuity, there will be more light penetration down to the shaded understory and more palms will be favoured after establishing in microsites under this conditions. These conditions would be more important for canopy palm species such as Oenocarpus bataua Mart. In Ecuador it has been recently showed that some understory palm species of the genus Prestoea and Geonoma showed preference for microsites with relatively high gap exposure (Svenning 2000). In Peruvian Amazon forest Astrocraryum seedling survival was found to be positively related to the amount of incident light (Cintra $\&$ Terborgh 2000). Forest architecture or the number of forest tree layers is also important and has been demonstrated to affect palm abundance in the Amazon (Kahn 1987). In our results the lack of effect of forest tree abundance on palm richness and abundance could be due to mass effects produced by the high tree species diversity (Shmida \& Ellner 1984).

In another site, $45 \mathrm{~km}$ from our study area a previous study (Kahn \& Castro 1985) on palm community found that the palm community differed in relation to soil hydromorphic conditions. There was a distinct palm community composition in upland forest (well drained soils), in what they called transition zone (poorly drained soils), and in seasonal swamp forest (water-logged soils). The authors found that palm population density was also affected by hydromorphic conditions and concluded that their highest density could be due to greater light intensity penetrating in the understory of the open swamp forest.

Similar results were found by Peres (1994) in terra firme forest near the Urucu River, who showed that the palm density including all species was greater in areas of poorly drained ( 81 individual/ha) than on well-drained, high forest soils (36 individuals/ha).

Microenvironmental topographic heterogeneity also can affect palm distribution and community composition at large spatial scale. Within an area of about 9,000 ha, a gradient of palm species was found to clearly follow a gradient in changes of relief at the Reserva Ducke (Lima, A.P. unpublished data).

Some results of our study confirmed, as early studies did, that palms are a very abundant group of plants in the Amazonian forest. They also suggest that variation in palm densities in the Amazon are not only related to changes in edaphic conditions, as most of the studies showed before, but can be also related to spatial changes in the variation of forest canopy openings and amount of leaf litter. 

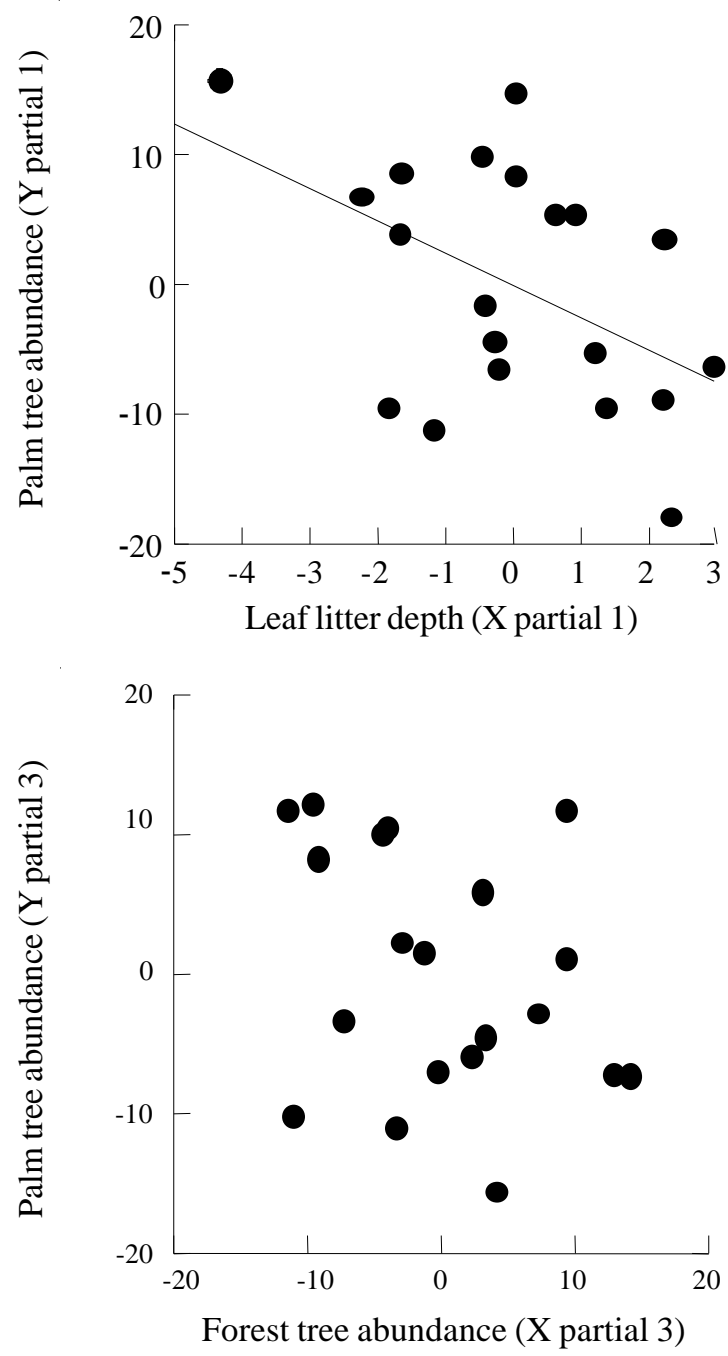

C

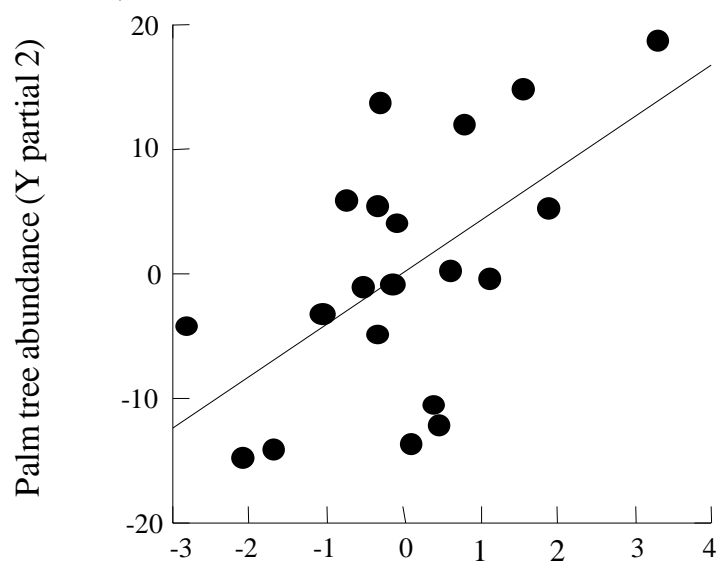

Forest canopy openness (X partial 2)

Figure 3. Partials of the multiple regression analysis of the effects of leaf litter depth (A), forest tree abundance (B), and forest canopy openness (C) on the dependent variable Palm abundance. The partials resulted from the analysis are presented in the table 3 .
A Acknowledgements - We want to thank INPA (Instituto Nacional de Pesquisas da Amazônia) for the logistics at reserva Ducke. We appreciated the review by Roger Hutchings on the English. The review by two anonymous reviewers and the editor Fábio de Barros was also appreciated. This study was financed by the first author. Paulo Assunção helped in identifying the palm trees during the field work. The system of trail grid at Reserva Ducke was opened in 1997-1999 and financed by the projects PELD-CNPq 40003/99-2 and PNOPg-CNPq - 520039/98-0.

\section{References}

ASHTON, P.S. 1989. Species richness in tropical forests. In Tropical forest: Botanical dynamics, speciation and diversity. (L.B. Holm-Nielsen, I.C. Nielsen \& H. Balslev, eds.). Academic Press, London, p.239-251.

BELBIN, L. 1982. PATN: Pattern Analysis Package. CSIRO, Canberra, Australia.

BRANDANI, A., HARTSHORN, G. \& ORIANS, G. 1988. Internal heterogeneity of gaps and species richness in Costa Rica tropical rain forest. Journal of Tropical Ecology 4:99-119.

CINTRA, R.1997a. Leaf litter effects on seed and seedling predation of the palm Astrocaryum murumuru and the legume tree Dipteryx micrantha in Amazonian forest. Journal of Tropical Ecology 13:709-725.

CINTRA, R.1997b. A test of the Janzen-Connell model with two common tree species in Amazonian forest. Journal of Tropical Ecology 13:641-658.

CINTRA, R.1998. Sobrevivência pós-dispersão de sementes e plântulas de três espécies de palmeiras em relação a presença de componentes da complexidade estrutural da floresta amazônica. In Floresta Amazônica: Dinâmica, Regeneração e Manejo (C. Gascon \& P. Moutinho, eds.). INPA, Manaus, p.83-98.

CINTRA, R. \& HORNA,V. 1997. Seed and seedling survival of the palm Astrocaryum murumuru and the legume tree Dipteryx micrantha in gaps in Amazonian forest. Journal of Tropical Ecology 13:257-277.

CINTRA, R. \& TERBORGH, J. 2000. Forest microspatial heterogeneity and seed and seedling survival of the palm Astrocaryum murumuru and the legume Dipteryx micrantha in an Amazonian forest. Ecotropica 6:77-88.

CLARK, D.B. \& CLARK, D.A. 1984. Spacing dynamics of a tropical tree: evaluation of the Janzen-Connell model. American Naturalist 124:769-788.

CLARK, D.B., CLARK, D.A. \& READ, J.M.1998. Edaphic variation and mesoscale distribution of tree species in a neotropical rain forest. Journal of Ecology 86:101-112.

CLARK, D.B., PALMER, M.W. \& CLARK, D.A. 1999. Edaphic factors and the landscape-scale distribution of tropical rain forest trees. Ecology 80:2662-2675.

CONDIT, R., HUBBELL, S.P. \& FOSTER, R.B.1996. Changes in tree species abundance in a neotropical forest: Impact of climate change. Journal of Tropical Ecology 12:231-256. 
CONNELL, J. 1978. Diversity in tropical rain forest and coral reefs. Science 199:1302-1310.

DE STEVEN, D.1988. Light gaps and long-term seedling performance of a neotropical canopy tree (Dipteryx panamensis, Leguminosae). Journal of Tropical Ecology 4:407-411.

DENSLOW, J.S.1987. Tropical rainforest gaps and tree species diversity. Annual Review Ecology and Systematics 18:431-451.

DENSLOW, J.S., NEWELL, E. \& ELLISON, A.M.1991. The effects of understorey palms and cyclanths on the growth and survival of Inga seedlings. Biotropica 23:225-234.

FOWLER, N. 1988. The effects of environmental heterogeneity in space and time on the regulation of population and communities. In Plant population ecology: The $28^{\text {th }}$ Symposium of the British Ecological Society (A.J. Davy, M.J. Hutchings \& A.R. Watkinson, eds.). Blackewell Scientific, Oxford, p.249-269.

GENTRY, A.H.1991. Four Neotropical Rainforests. Yale University Press, London.

HENDERSON, A.1995. The palms of the Amazon. Oxford University Press, New York.

HENDERSON, A., GALEANO, G. \& BERNAL, R. 1995. Field guide to the palms of the Americas. Princeton University Press, Princeton.

HUBBELL, S. \& FOSTER, R.B. 1986. Canopy gaps and the Dynamics of a Neotropical Forest. In Plant Ecology (M.J. Crawley, ed.). Blackwell Scientific Publishers, Oxford, p.77-96.

JANZEN, D.H. 1970. Herbivores and the number of tree species in tropical forests. American Naturalist 104:501-528.

KAHN, F.1987. The distribution of palms as a function of local topography in Amazonian terra-firme forests. Experientia 43:251-259.

KAHN, F. \& CASTRO, A. 1985. The palm community in a forest of central Amazonia, Brazil. Biotropica 17:210-216.

KAHN, F. \& MEJIA, K.1990. Palm communities in wetland forest ecosystem of Peruvian Amazonia. Forest Ecology and Management 33/44:169-179.

KAHN, F., MEIJIA, K. \& CASTRO, A. 1988. Species richness and density of palms in terra firme forests of Amazonia. Biotropica 20:266-269.

KILTIE, R.1981. Distribution of palm fruits on a rain forest floor: why white-lipped peccaries forage near objects. Biotropica 13:141-145.

LOSOS, L. 1995. Habitat specificity of two palm species: experimental transplantation in Amazonian successional forests. Ecology 76:2595-2606.

LUIZÃO, F. \& SCHUBART, H.O. 1987. Litter production and decomposition in a terra-firme forest of Central Amazonia. Experientia 43:259-265.

MACNALLY, R.C. 1994. On charactering foraging versatility, illustrated by using birds. Oikos 69:95-106.

MATOS, D.M.S., FRECKLETON, R. \& WATKINSON, A.R. 1999. The role of density dependence in the population dynamics of a tropical palm. Ecology 80:2635-2650.
MINCHIN, P.R. 1987. An evaluation of the relative robustness of techniques for ecological ordination. Vegetatio 69:89-107.

MOLOVSKY, J. \& AUGSPURGER, C.K. 1992. The effect of leaf litter on early seedling establishment in a tropical forest. Ecology 73:68-77.

PERES, C. 1994. Composition, density, and fruiting phenology of arborescent palms in an Amazonian Terra Firme Forest. Biotropica 26:285-294.

PITMAN, N.C.A., TERBORGH, J., SILMAN, M. \& NUNES, P. 1999. Tree species distribution in an upper Amazonian forest. Ecology 80:2651-2661.

RIBEIRO, J.E.L.S., HOPKINS, M.J.G., VICENTINI, A., SOTHERS, C.A., COSTA, M.A.S., BRITO, J.M., SOUZA, M.A.D., MARTINS, L.H.P., LOHMANN, L.G., ASSUNCÃO, P.A.C.L., PEREIRA, E.C., SILVA, C.F., MESQUITA, M.R. \& PROCOPIO, L.C. 1999. Flora da Reserva Ducke. Guia de identificação das plantas vasculares de uma floresta de terra-firme na Amazônia Central. INPA, DFID, Manaus.

RICKLEFS, R.E.1977. Environmental heterogeneity and plant species diversity: a hypothesis. American Naturalist 111:376-381.

SCARIOT, A.O.1999. Forest fragmentation effects on palm diversity in central Amazon. Journal of Ecology 87:66-76.

SCARIOT, A.O., OLIVEIRAFILHO, A.T. \& LLERAS, E. 1989. Species richness, density and Distribution of palms in an eastern Amazonian seasonally flooded forest. Principes 33:172-179.

SHMIDA, A. \& ELLNER, S.1984. Coexistence of plant species with similar niches. Vegetatio 58:29-55.

SVENNING, J-C. 1999. Microhabitat specialization in a species-rich palm community in Amazonian Ecuador. Journal of Ecology 87:55-65.

SVENNING, J-C. 2000. Small canopy gaps influence plant distributions in the rain forest understory. Biotropica 32:252-261.

SVENNING, J-C. 2001. On the role of microenvironmental heterogeneity in the ecology and diversification of neotropical rain-forest palms (Arecaceae). The Botanical Review 67:1-53.

SWAINE, M.D. \& WHITMORE, T.C. 1988. On the definition of ecological species groups in tropical rain forests. Vegetatio 75:81-86.

TERBORGH, J. 1986. Keystone plant resources in the tropical forest. In Conservation Biology: The science of scarcity and diversity (M.E. Soulé, ed.). Sinauer, Sunderland, p.330-344.

TERBORGH, J., FOSTER, R.B. \& NUNEZ, P.V. 1996. Tropical tree communities: A test of the nonequilibrium hypothesis. Ecology 77:561-567.

UHL, C., CLARK, K., DEZZEO, N., \& MAQUIRINO, P. 1988. Vegetation dynamics in Amazonian treefall gaps. Ecology 69:751-763.

WILKINSON, L. 1998. SYSTAT: the system for statistics. Systat, Evanston.

WING, S.L., HICKERY, L.J. \& SWISHER, C.C. 1993. Implications of an exceptional fossil flora for Late Cretaceous vegetation. Nature 363:342-344. 